\title{
Communicative resources and credibility in public discourse on refugees
}

\section{ABSTRACT}

This paper examines how communicative resources affect the construction of credible texts and identities in a public debate on Australia's treatment of a refugee. It centres on two key written statements - one from the Immigration Minister, and another from a Somali refugee. The analysis is divided into four levels, exploring the parties' respective linguistic, material, identity and platform resources, and how these impact their statements' creation and reception, and their participation in discourse creation more generally. The paper finds that there are inequalities on all four resource levels that largely undermine the refugee's ability to present a credible text and identity and challenge mainstream discourse on refugees. The paper demonstrates how a multi-level analysis of communicative resources can challenge assumptions about participation and uncover inequalities invisible in the prevailing discourse.

\section{INTRODUCTION}

In October 2015, the story of a Somali refugee gained significant media attention in Australia. The young woman, who was living in the small island nation of Nauru as a result of Australian refugee policy, sought medical assistance after becoming pregnant as a consequence of rape. The Australian government transferred her to Australia to be able to access medical services, including pregnancy termination; however she was returned to Nauru shortly afterwards without having the procedure. Her case was reported widely in the media, using the pseudonym 'Abyan'. A debate emerged over the reasons for Abyan's prompt removal from Australia, with the Australian Government insisting that she had decided not to have a termination and Abyan's Australian lawyer suggesting this was not the case. Media reports frequently referred to an official written statement issued online by the Immigration Minister following Abyan's removal, as well as a handwritten statement from Abyan herself, giving her version of events.

The media's presentation of this public debate assumed an equality of agency and voice between the Minister and Abyan. Problematizing that equality is the point of departure of the current study. Specifically this paper seeks to explore how the Minister's and Abyan's communicative resources determine how credibility is produced, reproduced and challenged in this debate. Credibility is the focal theme because in Australia, successive governments have gained popular support by building a heated and binary public discourse about whether people seeking asylum are 'genuine' or 'bogus' (i.e. not credible) (MacCallum 2002; Macken-Horarik 
2003b, 2003a; Stirling 2015). As explained in greater detail below, credibility was likewise a focus in the reporting and commentary on Abyan's case, which questioned who was telling the truth: the Immigration Minister or Abyan and, her lawyer and her advocates (see Smith-Khan Under review, which complements this paper by analysing a corpus of media articles about Abyan's case).

This paper examines the Minister's online statement and Abyan's handwritten statement, exploring these two speakers' respective communicative resources and demonstrating their inequalities across multiple levels. This aligns with the concern with discursive reproductions of power that underlies critical discourse analyses (van Dijk 2008). By doing so, this paper seeks to uncover the Minister's and Abyan's respective capacities to participate in the public debate about Abyan's experiences and to influence public discourse on refugees more generally.

The paper first outlines the background of the case. It summarises a related study on the media reporting on Abyan, as well as existing research on communicative resources and credibility construction. This is followed by an exploration and comparison of the Minister's and Abyan's communicative resources on four levels, in relation to the two written statements: linguistic resources, identity resources, material resources and platform resources. As set out in the final discussion and conclusion, this analysis confirms that there are significant inequalities between these two participants. This means that they have very different capacities to engage in the debate, to construct and defend their own credibility, and, in doing so, to contribute to the broader creation of discourse on refugees and refugee policy.

Therefore, the media's construction of Abyan's participation as a key debate participant is a dangerous misrepresentation that risks damaging her credibility even further, and more generally reinforces and contributes to a broader discourse that doubts refugees' credibility. This discourse justifies or encourages discriminatory treatment of refugees; their prejudicially presumed lack of honesty is presented as undermining their moral and legal entitlement to protection. This may help explain the introduction of increasingly restrictive or punitive policy, such as barring 'unauthorised' arrivals from applying for a refugee visa in Australia (Migration Act $1958 \mathrm{~s} 46 \mathrm{~A}(1))$.

The unequal communicative resources shown in this case study also call into question the procedural fairness of asylum applications, as application processes often heavily focus on whether or not the applicant is a credible witness, despite the applicant being under-resourced, relative to others in the process, to construct their own credibility (as I explore in Smith-Khan 2017c, 2017b, 2017a). Further, public discourse that questions refugees' credibility can lead - 
and arguably has already led - to a 'culture of disbelief' amongst refugee visa decision makers, creating obvious difficulties for applications that hinge on credibility (Baillot et al. 2014: 130; see also Hamlin 2014). Because inequality among different social actors in terms of their ability to influence the dominant refugee discourse has serious, potentially life-changing consequences, the forms such inequality takes in actual instances of communication and discourse production warrant illumination through scholarly analysis.

\section{'ABYAN', COMMUNICATION AND POWER}

\section{The Abyan debate}

As already mentioned, this case study focuses on the highly publicized case of a Somali refugee living on Nauru as a result of Australian Government policy. This young woman, 'Abyan', had travelled by boat to seek asylum in Australia. Under Australian policy, people who seek asylum without a visa are transferred to the Pacific island state of Nauru or Manus Island, in Papua New Guinea (PNG), and generally have no right or opportunity to be resettled in Australia (see explanation of policy in Opeskin and Ghezelbash 2016). Abyan had her asylum claim assessed on Nauru, was granted refugee status and then moved from the Australian-funded detention facilities into Australian-funded accommodation outside the detention centre, in Nauru.

At the beginning of September 2015, Abyan sought medical assistance with the health services contractor on the island when she became unwell, and it was discovered that she was pregnant. She reported to the health contractor that this was due to having been raped by a Nauruan local, some two months earlier. Her report came amidst similar ones made by other young female refugees on Nauru, including another Somali refugee who reported her rape to the Nauruan police. That case was dismissed for lack of evidence, and the claimant was later publicly criticized by the Nauruan Government. Further, the Australian PR company representing the Nauruan Government made her name public (Allard 2015; Doherty 2015).

Following her first contact with health officials, Abyan's case was brought to the attention of the Australian media and public in early October by Australian lawyer, George Newhouse. Identifying himself as her lawyer, Newhouse spoke to the media and launched a petition, calling on the Australian Government (hereafter, the 'Government') to bring Abyan to Australia for 'urgent medical treatment' (Newhouse 2015). Pregnancy termination procedures are not available on Nauru and medical facilities there are generally limited. Thereafter, Abyan's situation was acknowledged by the Government, and arrangements were made for her transfer. 
On the $11^{\text {th }}$ of October, Abyan was flown to Brisbane, Australia, where she visited a hospital, before being moved to a detention centre in Sydney the following day. She was flown back to Nauru five days later, on the $16^{\text {th }}$ of October, without terminating the pregnancy and without meeting her lawyer. This was despite Mr Newhouse seeking an injunction in court to prevent her removal, as this happened too late: she was already out of the country.

Abyan's precipitous removal attracted criticism and led to a public debate over the reasons why she was removed so soon after arriving. The then Immigration Minister, Peter Dutton (hereafter the 'Minister'), and other Government officials made several statements related to the case, all claiming that Abyan was removed because she had decided not to proceed with the termination. His first statement after Abyan's removal is the first key text analysed in this paper. The day after the Minister made this statement, Mr Newhouse shared a handwritten statement from Abyan with the media. This is the second key text analysed in this paper. Abyan was eventually returned to Australia towards the end of October for further medical assistance (Anderson 2015).

A Freedom of Information (FOI) request led to the release some months later of a chain of emails between various Government officials regarding Abyan. These communications, which were shared with the media following their release in January 2016, largely confirmed the advocates' and Abyan's claims (Symons-Brown 2016). They included emails from a health official, who described the last discussion with Abyan, based on which it had been claimed that she had decided not to have a termination. The official explained:

Unfortunately despite 30 mins on the phone to [the Telephone Interpreting Service] I was unable to access a Somali interpreter. She does, however, understand and speak very basic English and was happy to proceed with the consultation. She confirmed that she does not want the termination now, but she did make it clear that she hasn't completely changed her mind (p. 77).

During investigations following Abyan's return to Nauru, the same official further responded:

...after she declined the procedure I asked her (more than once) whether she changed her mind and no longer wanted a [termination of pregnancy (TOP)]. She consistently said that she still wanted to have a TOP, she just didn't want it that day or the following week ...I explored her reasons for declining the procedure but she just stated that she 
felt 'too mentally unwell' and wouldn't elaborate....I asked whether she had changed her mind altogether, and she said no.... (pp. 93-94).

It appears likely that the Government officials were aware that Abyan was far from having made a final decision regarding the termination. The above emails also suggest that there were issues that undermined Abyan's ability to communicate with the medical professionals she interacted with, such as not having access to an interpreter and relying on limited English language skills. This may have undermined Abyan's ability to give informed consent to participate in this pivotal final consultation in the first place - a point that appears to have been overlooked by the health official, who characterizes her limited response as Abyan choosing not to 'elaborate' (similar examples are analysed in Angermeyer 2016: 168, where nonEnglish-speaking litigants were led to agree to arbitration in situations where they were not always properly informed about the consequences of doing so). Abyan had also flagged her mental health as a barrier to making such an important decision. Therefore it is clear from the above emails that the Government's claim that Abyan had made a decision not to have a termination was tenuous at best.

Further emails indicate a likely motivation for Abyan's swift removal: the Government's wish to prevent legal action that would keep her more permanently in the country. For example, on $14^{\text {th }}$ October, a senior official wrote:

If she decides to proceed, she will then be returned to Nauru as soon as medically fit to travel. If she decides not to proceed, we will make arrangements to have her return to Nauru ASAP. If she continues to vacillate, we will make a decision early next week about return to Nauru. I think the lawyer is buying time so he can seek legal intervention (p. 25).

Following Abyan's return to Nauru, there were relatively few media reports on the ongoing events affecting her, including the Government's announcement that it would return her to Australia for further treatment. Even fewer articles shared the release of the documents from the FOI request in January 2016. Those last articles indicated that Abyan was then still in Australia, 'receiving medical care' (Tranter 2016), but there is no other more recent publicly available information regarding her case. 


\section{Abyan in the media: credibility, refugee discourse and power}

Previous research has established the problematic assumption on which this paper's examination of two key texts is based, namely the construction in the public discourse of an equality of agency and voice between the Minister and Abyan. In particular, this paper follows on from a separate study by the author (Smith-Khan Under review) of a corpus of 15 news articles, representing a cross-section of the Australian media, ranging from publications which are generally supportive of the conservative government, to those considered more 'leftist'.

By analysing the discursive representation of the key social actors (van Leeuwen 1996) in the reporting on this case, the media study found that the majority of news articles presented Abyan as a key participant in the public debate regarding the events surrounding her treatment and experiences. The study found that this construction was achieved by presenting Abyan as an agent in sentences where she was assigned verbs related to speaking, such as 'claims' and 'reports'. These types of actions were also those she was most commonly assigned, in all but one article in the media corpus ( $36 \%$ of all actions). The impression of an equal debate between two key parties was further reinforced in that the structures in which the Minister most commonly (and almost uniquely) appeared as a named agent were similarly those involving him speaking or commenting on the case. For both actors, the frequency of these types of constructions contrasted sharply with the relative infrequency of actions directly involving Abyan's experiences or treatment. The study further noted that the existence of a debate between these two parties was produced by misconstruing Abyan's statement as explicitly accusing her 'adversaries' of lying. For example, one news article in the corpus claimed that Abyan said that the Immigration Minister's 'description of events - backed by Prime Minister Malcolm Turnbull - were false' (Allard 2015) and another stated that 'she said the government was not telling the truth' (Doherty and Medhora 2015).

Overall, the media study argued that by presenting the situation as a public debate to uncover one true version of events relating to Abyan and focusing primarily on the credibility of the various key actors, the reporting contributed to and reinforced the existing broader public discourse on refugees.

Indeed, the impact of the media's presentation of Abyan's case extends beyond how it affects her personally. In other studies, it has been found that individual stories or events are often used in support of more general arguments about refugee policy (for examples from Canada and Australia, see respectively Lawlor and Tolley 2017; Macken-Horarik 2003b). This was also the case for the reporting on Abyan, where her situation was almost always explicitly 
linked to more general debates about refugees, across a variety of media sources, regardless of political leaning. The journalists critical of government policy contextualize her experiences in offshore detention and explain how, for example, 'the government likes to pretend, disingenuously, that it is at arms length [sic] from much of what happens in those places' (Grattan 2015). Those in favour of these policies contextualise her case with a more positive framing of Nauru, referring to, for example, 'Abyan's beachside refugee housing complex' (Kenny 2015) and the provision of 'housing, a living allowance and employment opportunities' for 'resettled refugees' in Nauru (Kelly 2015) (see Smith-Khan Under review). Therefore, the way Abyan was presented by the media stands not only to affect Abyan herself, but also to contribute to broader discourse on refugees.

It is unsurprising that the prevailing public discourse often portrays asylum seekers and refugees in a negative light given that they are evidently not its creators, and are likely to have limited opportunities to challenge it, let alone control its production. In his discussion of the power of discourse to frame ideas and to empower certain perspectives over others, van Dijk (2008) explains:

We must ask who has access to the fundamental power resource of public discourse, who has access to political discourse, educational discourse and scholarly discourse. Who is able to control production of such discourse, as is the case for press conferences and press releases and other ways of influencing journalists and media? Because once you control part of the production of public discourse, you also control part of its contents, and hence, indirectly, the public mind - maybe not exactly what people will

think, but at least what they will think about. What we find is that while 'white' elites control such public discourses and their production ethnic minorities and immigrants have virtually no access and hence their views and opinions seldom reach the press and public opinion. They are mostly only talked about, and usually negatively...Hence power is related to control, and control of discourse means preferential access to its production and hence to its contents and style, and finally to the public mind (van Dijk 2008: viii, my emphasis).

Given the centrality of credibility as a theme in the reporting on Abyan, and the way her story is discursively linked to broader public debates on refugees, this paper explores how credibility is produced, reproduced and challenged in this debate. While the below examination sets out a number of potential negative interpretations of Abyan's language use, it is possible 
that uptake could vary across audiences. However, this is not the fundamental point of concern. Rather, given that equality of power is questioned in the current case study, the analysis involves a detailed examination of the key speakers' communicative resources and how these affect their ability to participate credibly in the debate, and their broader capacity to contribute to and challenge discourse.

\section{CREDIBILITY AND COMMUNICATIVE RESOURCES IN THE ABYAN DEBATE}

This paper centres on a dispute over facts between the Immigration Minister and the Australian Government on one side and Abyan and her lawyers and advocates on the other. Two key written statements, mentioned earlier, enumerate the two versions of events. The first (reproduced in Figure 1), published online on $17^{\text {th }}$ October 2015, was the Minister's first official statement after Abyan's removal from Australia. The second (reproduced in Figure 2), a handwritten statement, was released to the media by Abyan's lawyer the following day, largely contradicting the claims the Minister made in his statement and in other opportunities he had to speak to the public, both through the media and in Parliament. Mr Newhouse and various refugee advocates also communicated directly with the media, taking part in interviews and making public statements through other means, such as online petitions.

FIGURE 1. Minister's statement, 17 October 2015.

FIGURE 2: Abyan's statement, 18 October 2015.

In what follows, the paper's theoretical approach is explained and the two key texts are introduced, along with an examination of how their respective authors present the debate. Each author's respective communicative resources are then explored on four different levels: linguistic, identity, material and platform. On each level the analysis considers how the credibility of these two texts (and their authors) may be promoted, defended or challenged as a result of the authors' communicative resources and constraints.

Exploring communicative resources and credibility in the Abyan debate

In exploring the connections between language and power and explaining the concept of 'cultural capital', Bourdieu (1992: 55) argues that: 
The competence adequate to produce sentences that are likely to be understood may be quite inadequate to produce sentences that are likely to be listened to, likely to be recognized as acceptable in all the situations in which there is occasion to speak.

The analysis below draws on this concept of 'cultural capital', proposing and examining the four different types of resources Abyan and the Minister have at their disposal to present themselves and their respective texts as credible, in this public debate.

It was acknowledged in the public statements and in the Government email communications that Abyan had limited proficiency in English. This is also evident in her written statement, which is included and analysed in the following section. Language proficiency can have significant effects on the ways individuals are able to participate in society. Further, as Bourdieu indicates, what is important is not the ability to produce specific linguistic forms, but rather whether particular language use is likely to be accepted and valued in a given context. At worst, when speakers do not have the requisite competence it may compound situations of injustice. For example, while a person who speaks English as a second language may feel comfortable explaining something in an informal conversation, they may not be able to communicate the same information in a formal setting with strict communicative requirements, such as in a court hearing. In such a situation, the inability to communicate in the prescribed way may limit or distort the information the speaker is able to share, or even completely silence them, with potentially very serious repercussions. This is illustrated neatly by a case analysed in Piller (2016: 60-61), where a man contesting parking fines was able to explain his situation clearly to a court volunteer outside the courtroom but then made no response when before the magistrate (for other examples involving minority speakers' experiences in court see Angermeyer 2015; Eades 2003, 2008, 2012).

The way in which a spoken or written text will be interpreted by its audience depends on more than just the way language is used. The author's identity, including how it is perceived through the text's multimodal elements, such as pictures and visual framing, may influence its reception and play a role in creating meaning (see Blommaert 2004; Macken-Horarik 2003b; van Leeuwen 2007, for examples of multimodal analyses). Some speakers benefit from the power of their personal or delegated authority to legitimate their speech (Bourdieu 1992: 10713; van Leeuwen 2007: 94).

However, legitimate usage depends on more than just identity: language must be delivered in a legitimate form and context (Bourdieu 1992: 113). This means that material factors such as the medium of publication are also of importance, and whether the form they 
take is considered valid, valuable and legitimate will depend on the socio-political context (as argued in Teo 2000, who explores racism in Australian newspaper reporting; and in van Dijk 2006, analyzing political speech in the UK). Blommaert's (2004) case study of documents produced by an African asylum seeker in Belgium is an apt example. There, it was argued that the text's value - and ultimately its author's credibility - may be undermined in the Western bureaucratic context in which it is received, due to expectations regarding written language, such as consistency and accuracy of spelling, which may not have applied in the country of origin.

Ultimately, to influence discourse, the communicated opinion or version of events must be able to 'make an impress' on a particular audience (Piller 2017: 43). Regardless of language, whether a particular version of contentious events is accepted as the truth 'will depend upon the degree and pattern of its admission into communicative events' (Hymes 1974: 18, as cited by ; Piller 2017: 40). In other words, not only must the form and substance of what they say be acceptable to their interlocutors, the successful party needs to have the platform required to ensure their version of events reaches the intended audience: they must have the best opportunities to speak and be heard.

\section{Linguistic resources}

To be successful in political discourse requires 'special training', as Bourdieu (1992: 176) explains. This entails not only acquiring the corpus of specific kinds of knowledge ... produced and accumulated by the political work of the professionals of the present or the past'. It also requires 'mastery of a certain kind of language and of a certain political rhetoric' (Bourdieu 1992: 176). The Minister's statement reflects this training, mobilizing the specific linguistic resources required for the particular context in and for which the text has been produced. Furthermore, it is free from any grammatical or spelling error and includes a variety of syntactic structures that result in a carefully crafted text that strategically aligns with and contributes to the prevailing political discourse on refugees.

Abyan is de-personalised and anonymised as far as possible, consistently referred to simply as 'a woman' or 'the woman'. At no point is there any mention of her status as a recognised refugee, or her Somali nationality or any other aspect of her individual identity or experience. This is consistent with how the Minister describes her elsewhere also, referring to 
her only by gender (e.g. calling her 'the lady', during a press conference outside Parliament House (Bourke 2015)). By referring to her gender rather than her status as a recognised refugee, any human rights-related responsibilities Australia may have related to her refugee status on either a moral or legal level are backgrounded.

Grammatically, Abyan is allocated a passive role in relation to her movements to and from Australia and the treatment she receives. She "was flown by charter flight from Nauru to Sydney for a pregnancy termination' and 'was chartered back to Nauru' and 'was brought to Australia for medical attention, not for a migration outcome.' This is contrasted clearly with one case where Abyan is allocated an active role: 'The woman has decided not to proceed with the termination'. This contrast adds weight to the truth claim of this statement: Abyan is framed here, as the subject of the active verb, as having made a clear and definitive choice about the termination. This is important, as it is the central issue in contention between the different parties involved in the debate. No information is given about how she came to make this decision, how she communicated it, or to whom.

The third and fourth sentences in the Minister's statement contrast sharply with the first two: 'Comments from some advocates to the contrary are a fabrication, while others appear to be using this woman's circumstance for their own political agenda. They should be ashamed of their lies.' After the impersonal and neutral language used in the first two sentences, this paragraph is particularly emotive: advocates should be 'ashamed'. Their credibility is directly challenged with the two nouns they are presented as possessing: a 'political agenda' and 'lies'. The advocates' comments are 'fabrications'. Thus, the advocates involved are assigned a negative moral position.

Without explicitly pointing to the Government or the Minister himself, this presents the Minister as occupying a relatively higher moral position. Finally, by suggesting that the advocates' actions stem from 'their own political agenda', the reader is left to understand that the advocates are selfish ('their own' can be taken as being motivations apart from what is best for Abyan herself) and politically motivated. The choice of the term 'advocates' rather than 'lawyers' also accentuates the political nature of their actions, given that advocates are understood to be politically motivated actors, as opposed to lawyers, who carry out professional functions for their clients.

Once again, the unspoken opposite position is then occupied by the Government, whose decisions can be assumed to be more neutral or selfless. The Minister's choice not to explicitly refer to himself or the Government directly in relation to Abyan's situation has an additional effect beyond this. It acts to distance the reader's attention from the reality that the Government 
and the Minister are in fact powerful decision-makers and agents, and of course have their own motivations, aims and expectations. However, by mentioning Abyan's decision, and the advocates' 'fabrications' and 'agenda', we are led to focus on these actors as the sole or primary agents who brought about the set of events as they unfolded, assigning them primary responsibility for the outcomes. This is further entrenched by the lack of mention of any other actors (as becomes clearer when contrasted with Abyan's statement).

In contrast with the Minister, Abyan's linguistic resources are limited in this context. While Abyan's full linguistic repertoire is not public knowledge, her resources in English, the language mandated in the circumstances of the 'debate', are limited. Her language and literacy skills might be valuable elsewhere, but that value does not transfer into the setting under consideration. Abyan's situation thus resembles that of the Burundian asylum seeker whose written documents were examined by Blommaert (2004). The issue is that as texts move 'from the peripheries of the world system to its centers...this move in space is also a move across different economies of literacy, involving differential allocation of function and value' (Blommaert 2004: 661).

Abyan's statement includes a number of features that suggest she has limited English language proficiency. While we cannot be sure that she wrote this statement independently, it can be assumed at best that it represents her written proficiency in the English language and that, if she did receive assistance preparing it, her proficiency is even lower. In the statement, Abyan frequently uses the personal pronoun 'I' and recounts her experiences. For example:

I have been very sick

I have never said that I did not want a termination

I never saw a doctor,

I saw a nurse at a clinic

I saw a nurse at Villawood

I asked... to talk with my lawyer

Further, she also makes a number of errors. These include three obvious spelling errors, including one in the heading, 'Statemet', incorrect use of uppercase letters and inconsistent and insufficient punctuation, leading to run-on sentences.

Applying international guidelines for measuring language proficiency, these features would suggest that Abyan has only a basic ability. For example, the Common European Framework (Council of Europe 2018: 75) describes level A2 ('Basic User - Waystage') writing 
ability as including the ability to 'write about everyday aspects of his/her environment', produce 'short, basic descriptions of events, past activities and personal experiences' and use 'basic, concrete vocabulary and simple phrases and sentences with simple connectives like "and", "but" and "because"". The simple, repetitive structures Abyan uses to recount her personal experiences resemble this description.

Limited proficiency in written (and presumably spoken) English understandably restricts Abyan's ability to engage in the debate in the way the Minister and other actors can, for example by using a wide range of tenses and complex, multi-clause sentences. As a person with limited access to English language and literacy, and limited assistance, she would have been at a distinct disadvantage in terms of her ability to navigate the Australian legal system or advocate for herself in the political sphere (see discussions of similar cases involving persons for whom English was not a first language in Angermeyer 2015, discussing participants in Small Claims Courts in New York; and Eades 2012, discussing the case of a group of young Aboriginal litigants, their treatment in court and depiction in the media). This is without even considering lack of pragmatic competence or sociocultural or contextual knowledge about how best to appeal to the Australian public as an audience. Further, while likely resulting from limited proficiency, the use of repetitive single-clause or compound sentences with 'I' as the subject may also have the effect of overemphasizing agency and suggesting self-centeredness.

Limited English language proficiency does more than restrict the grammatical structures Abyan has at her disposal. Errors in written texts have been found to have a negative effect on how readers perceive the writer. For example, Appelman and Bolls (2011) found that readers were less likely to believe news articles that contained grammatical errors. Spelling errors in job applications have been found to elicit similar negative perceptions, including decreased credibility (Martin-Lacroux 2017). Finally, arguments in online student forums are less likely to be accepted when they contain spelling or grammar errors (Jeong et al. 2017).

While in certain settings, such as in education and business, non-native speakers' errors may be treated with some leniency (Wolfe et al. 2016), this may not be the case for Abyan, who is identified neither as a student or a professional. Rather, Abyan's audience may perceive her lack of proficiency as a sign of laziness or lack of effort, based on the problematic assumption that anyone can learn a language if they work hard enough (see Blommaert 2004; Piller 2016: 42-50). Language skills and migration outcomes are often linked: proving a certain level of language proficiency is increasingly a prerequisite to obtaining (and meriting) citizenship in the global north (Capstick 2016: 81). 
As a refugee, Abyan may even find herself trapped between two competing, negative discourses on migrant language learning: if she were too fluent in English, this could also undermine her credibility. It would clash with common assumptions about refugees having poor English skills. This assumption is apparent in other media reporting, like the 2009 case of a Sri Lankan asylum seeker interviewed in the media whose refugee status was questioned due to his high level of education and skills in the English language (Piller 2016: 54-55). The same assumption has also been identified in refugee status determination (RSD) processes, for example, the instruction to Kosovars attempting to speak English that 'proper refugees were not expected to know foreign languages' (Jacquemet 2011: 482). In RSD, it also manifests when asylum seekers' country or group of origin is contested and their language use indexes an origin that clashes with institutional expectations. For example this caused an issue for 'Joseph', an asylum seeker whose claim to be Rwandan was disbelieved because of his use of English, which ironically was a product of his displacement (Blommaert 2010. See also ; Campbell 2013; Corcoran 2004; Eades 2005, 2009; Maryns 2004).

The different linguistic resources that Abyan and the Minister (and his officials) have result in two very different texts. Paradoxically, Abyan's being limited to 'I'-subject structures may create the perception of control or agency. Yet, as argued above, these simple structures suggest that she has limited proficiency in English, meaning that she is more restricted in the way she can speak about her situation and defend her credibility to an Australian Englishspeaking audience. The spelling and grammatical errors in her text further threaten its legitimacy. This contrasts clearly with the Minister's text, which includes a variety of linguistic devices supporting the Government's presumably preferred representation of the various actors involved: absent or invisible actors from the Government's side, in passivized phrases, emotive language to describe the advocates' motives, and an active structure to describe Abyan's decision-making. What the above crucially demonstrates is that the two authors' unequal access to linguistic devices has an impact on their respective ability to craft credible statements and support the creation of credibility-specific refugee discourse.

\section{Identity resources}

It is impossible to examine linguistic proficiency and its reception in isolation: the way communication is perceived is inherently linked with its speaker or author. As Piller (2016: 14) explains: 
In linguistically diverse societies injustices arise because the ways in which people communicate are valued differently. The language practices of those who are disadvantaged in other ways - because of their legal status, their gender, their race, or their class - are usually the ways of speaking that are least valued, and language thus becomes one aspect of cumulative disadvantage in diverse societies.

A recent study of the use of the term 'broken English' across two large corpora similarly found that this descriptor was more likely to be applied to low-status persons, and in texts presenting these individuals in a negative light, or with suspicion (Lindemann and Moran 2017). Therefore, while Abyan's linguistic resources may impact the way her identity is perceived by her audience, her identity resources may also impact the way her communication is interpreted.

The same is true of the Minister. In this situation, Peter Dutton does not speak as a private individual, but rather as the Minister - a senior Government representative. The language of his titles further reinforces his status and credibility. He is an MP - a member of Parliament - an institutional insider. He is also the 'Hon.' - Honourable. Therefore, his communication is legitimized by the authority vested in him by this institution.

Moreover, whether or not they agree with his politics or decision-making, the Australian public know who Peter Dutton is - they regularly come across his name, his face, and the sound of his voice. It is possible to find his CV online, and read his biography, know where he has lived, who his family is, where he studied. These details act to personalize him he is a real and complete individual.

In contrast, the reader knows very little about the person being called Abyan. While she has been given this pseudonym presumably in an attempt to personalise her, there is really very little available information about her beyond her age, gender and nationality. This lack of information is not coincidental. At least in part, it is the inevitable result of concerted efforts by the Australian Government to limit the transparency of their programs in Nauru, PNG and Australian onshore detention centres. This is explained in greater detail below.

Further, the nature of the events which brought her into the public eye may mean that Abyan does not wish to publicise her identity or discuss details of her experiences - indeed, her response to the journalist, Chris Kenny, when, as discussed below, he sought to interview her, suggests this may be the case. Healicon (2016) describes the traumatic process sexual violence survivors undergo after making a complaint: 
It is this evaluation of her personhood, the assessment of her credibility, that is prioritised over scrutiny of incidents of abuse and the role of the perpetrator in them. If deemed credible and therefore believable, then sexual violence took place and she is legitimated as a victim of abuse. If not, then she is castigated as a liar. Either way, the implications for her sense of self are significant (Healicon 2016: 41).

Aside from potentially wishing to remain anonymous to avoid the social stigma and psychologically damaging scrutiny that victims of rape may attract, revealing her identity could put her in physical danger. She has been the victim of rape by a local person in a very small community (Nauru has a population of just over 11,000 people (Central Intelligence Agency 2018)) in which she has a limited ability to defend herself or remain safe. This places Abyan in an impossible situation: she may wish to remain private and anonymous, but in doing so, she is restricted in how she constructs a credible identity for those questioning the credibility of her claims.

Research on the visual representation of refugees in Australian newspapers elucidates the effects of a lack of personalising information. Bleiker et al. (2013) studied the depiction of refugees and asylum seekers on the front pages of two main Australian newspapers, finding that the scarcity of images of individuals led to a dehumanisation of refugees: readers find it much harder to empathise with groups of unknown persons. They argue:

The images [of large, anonymised groups] that dominate media coverage of asylum seekers are thus unlikely to evoke the type of compassion in viewers that images of a single victim with clearly recognisable facial features trigger (Bleiker et al. 2013: 411).

Likewise, in his review of UK newspaper discourse on refugees and immigrants, KhosraviNik (2009) found that positive discourses about migrants were presented by providing individuals' personal details to humanise them and create empathy.

Therefore, for Abyan, the lack of detailed information available about her as an individual limits the potential for building trust and empathy, effectively undermining the perceived legitimacy of her written statement. The lack of details publicly available about her also makes it possible for other actors to present her in a variety of ways - anything from helpless victim to conniving foreigner, as there is little available information to contradict these or any other constructions. 
Further, the only elements of Abyan's identity that are publicly available are potentially problematic, being categories the Australian public are taught to mistrust: she is a 'foreigner', a refugee and a woman who has claimed to have been raped. 'Foreign' identity can impact on interlocutors' perception of linguistic proficiency (as discussed above) and in turn can undermine their assessments of a speaker's knowledge and the quality of what they say (see discussion in Piller, 2016, p. 53). Her identity as a refugee is unlikely to contribute in a positive way to her credibility, given the fact that the trustworthiness or genuineness of people seeking asylum is a key concern in mainstream Western public and media discourse (see for example findings in Every and Augoustinos 2008; Pickering 2001) and that testing their credibility is often a prerequisite to accepting the refugee narrative they rely on to obtain a refugee visa (as discussed, for example, in Smith-Khan 2017c, 2017a; Sweeney 2009). Similarly, as explained above, when a woman claims to have been raped, this triggers a process of assessing her credibility, as a prerequisite to determining the veracity of the claim (Healicon 2016). Therefore the three elements of Abyan's identity to which the public is privy only reinforce the questionable nature of her credibility, rather than act to support it.

The above demonstrates that Abyan and the Minister have unequal identity resources that impact the way their communication is likely to be interpreted and trusted. This creates an advantage for the Minister, who is able to harness superior identity resources to add credibility to his statement, while there is little to draw on for the public to perceive Abyan as trustworthy.

\section{Material resources}

There is a clear contrast between the two statements in terms of their provenance and medium, demonstrating the different material resources Abyan and the Minister have to support their credibility.

The Minister's statement has a number of features that support its legitimacy. It is published on an official government website, alongside a plethora of similar statements released throughout his term in office, and more broadly amongst many official texts published by his department. It is published and stored directly by the institution responsible for its creation, rather than relying on intermediaries for its distribution. The text is given further authority by the Minister's official header and Government coat of arms, a fixed URL and uniform, conventional formatting and font style. These features index his status as an elected government official.

Abyan's statement appears in a photographed image of a lined piece of paper, on a wooden table top, torn from an old diary, on the page showing the date of the $25^{\text {th }}$ December 
(creating a factual mismatch with the actual date on which it was written), and handwritten using a blue pen.

Titled 'Statemet', this text somewhat resembles the statutory declarations or statements common in asylum applications. Writing a statement like this is thus a deployment of communicative resources to resemble a particular genre which is given high value in official, government/bureaucratic settings. However, the fact that it is handwritten suggests something lacking - official statements in legal and bureaucratic settings are most commonly typed. The paper and writing in this case thus suggest a lack of professional assistance and a deviance from the expected norm. Further, the parallels with the refugee statement suggest that the text represents a contested version of events: refugee narratives are the subject of close scrutiny, with credibility assessments often a pivotal prerequisite to believing their contents (this is acknowledged in an extensive body of literature. See, for example, Sweeney 2009). This means that from the outset, the genre of the text suggests to the reader that the truth of its contents is a matter to be determined, rather than accepted per se.

The fact that Abyan's statement appears in this medium suggests that she lacks the resources to communicate in other, arguably more legitimate forms. However, even if she had access to a computer and the internet, she would still lack the ability to present her statement on an official website in the way the Minister can.

\section{Platform resources}

As eluded to above, the opportunity the speakers have to construct and defend their credibility also depends on the platforms they have from which to communicate. Although this paper primarily focuses on only one statement from the Minister, in reality he, and the Government more generally, have many opportunities to speak about Abyan's case. Conducting the earlier media study (Smith-Khan Under review), it became clear that there were numerous occasions on which the Minister and his colleagues publicly commented on the case:

7 Oct: Minister speaks to press outside Parliament

12 Oct: Attorney General is questioned in Parliament

15 Oct: Minister is interviewed on $2 \mathrm{~GB}$ radio

17 Oct: Minister issues the statement

17 Oct: Prime Minister responds to questions at press conference with NZ PM

19 Oct: Minister is interviewed on Sky News (TV)

19 Oct: Minister is interviewed on $\mathrm{ABC}$ radio 
19 Oct: Senate Estimates Inquiry regarding Abyan - various officials questioned in detail

19 Oct: Minister answers questions in Parliament

19 Oct: Minister speaks at Press Gallery Doorstop

20 Oct: Minister speaks at Press Conference

22 Oct: Minister is interviewed by $2 \mathrm{~GB}$ radio

23 Oct: Minister speaks at Press Gallery Doorstop

26 Oct: Minister is interviewed by $2 \mathrm{~GB}$ radio

28 Oct: Minister is interviewed on Sky News (TV)

29 Oct: Minister is interviewed by 2 GB radio

30 Oct: Minister is interviewed on ABC Breakfast (TV)

8 Nov: Minister is interviewed on ABC Insiders (TV)

Beyond these occasions, it should also be recognised that the Minister and the Government would have been, and remain, able to publicly comment on Abyan's case, whenever deemed appropriate or beneficial.

In contrast, Abyan had very limited chances to speak and, in many cases, the limitations she had were the intended result of explicit government policy. We cannot be sure what information she had regarding her case, or knowledge of how it had been discussed in Australia. We do not even know what role she played in drafting the handwritten statement: whether a lawyer or someone else guided her in its content, whether she physically wrote it or orally made this statement herself, or whether she was assisted by another person.

Refugees and asylum seekers in detention in Australia and those transferred to Nauru or PNG are largely inaccessible to the Australian public and media as a direct consequence of government policy. This policy has emphasised limiting the transparency and public scrutiny of these operations and effectively excludes refugees and asylum seekers from accessing Australian courts. This has included legislative measures to restrict access to and sharing of information concerning refugees in detention, as well as visa changes in Nauru.

In 2014, the Government of Nauru raised the visa charges for media representatives from AU\$200 to an AU\$8000 non-refundable fee (The Government of the Republic of Nauru 2017). Journalists from various Australian and international news outlets have reported being denied a visa, sometimes even before making a formal application, leading some to suggest that a de facto ban on foreign media has been established in the country (ABC Media Watch 2015). There had been no media visa grants for 18 months before Chris Kenny was granted a visa and travelled to Nauru, coincidentally around the same time as Abyan's return there. 
Kenny is a journalist for The Australian, a newspaper with a conservative readership (McKnight 2012), and previously worked as Chief of Staff for politicians in the Liberal Party (the conservative party in government in Australia from 2013 onwards) at both State and Federal levels (Sky News). The fact that he was granted a visa when many other journalists were not, as well as the nature of his interactions with Abyan while in Nauru, drew criticism. In fact, his two interviews with Abyan, one of which involved taking her photograph and the presence of local police, were the subject of their own separate debate: advocates claimed that Kenny forced Abyan to participate in the interviews (a claim he denied), and Abyan reported 'media harassment' (ABC Media Watch 2015; Allard 2015). Government policy that restricts access to Nauru to all but a select few journalists in this way limits media scrutiny of Australia's refugee policy and more specifically in this case, access to Abyan herself. This is a clear example of the government's influence over the production of media reporting, and over Abyan's opportunities and options to engage in the debate, and thus its control of the public discourse.

The Australian Government has also taken legislative steps to limit the sharing of information concerning refugees in Australian detention or in facilities in Nauru and PNG. It introduced secrecy provisions in its Border Force Act 2015 to prevent Government employees and contractors who work with refugees from reporting concerns regarding their treatment, attracting a penalty of two years' imprisonment (section 42). Only later, under public pressure, health professionals were exempted from this provision, and following a legal challenge the provisions are to be amended to further limit their application (Gartrell 2017).

The Government also took punitive measures in response to contracted workers in Nauru who made public claims about sexual abuse occurring in detention there. A group of workers from Save The Children, the contracted organisation operating in detention in Nauru at that time, were suspended from their employment following these claims, although they have since successfully obtained compensation for their treatment, following two inquiries and legal action (Whyte 2017).

Finally, the Government has also attempted on multiple occasions to limit asylum seekers' communication means while in detention, most recently seeking to pass legislation (Migration Amendment (Prohibiting Items in Immigration Detention Facilities) Bill 2017) to prevent those detained in Australia from having mobile phones, arguing that they could be used for criminal activities (Davidson 2017).

Therefore, Abyan and the Minister have very different platforms from which they can communicate and construct and defend their credibility. In large part, Abyan's opportunities to 
participate are directly undermined by policy created by the Minister's own government department, reflecting a further dimension of inequality and a clear aim to restrict the platform resources of refugees like Abyan.

\section{DISCUSSION AND CONCLUSION}

This paper has examined Abyan's written statement and a statement of similar length issued by the Immigration Minister a day earlier. It set out to challenge the media's discursive construction of the two parties as equal debate participants, by critically analysing four levels of communicative resources in these statements, and uncovering the large asymmetries between their authors, in terms of their ability to construct and defend their own credibility an essential prerequisite to gaining audience trust.

While the Minister (and Government) and Abyan may be considered two parties presenting conflicting versions of a set of events, their very different communicative resources lead to a power imbalance in terms of how they are able to produce and defend their respective credibility. The Minister and the Government start from a position of authority and have access to a wide range of highly-valued means and frequent opportunities to communicate and clarify their position. In contrast, Abyan is limited in her ability to construct a trustworthy identity and has few resources and opportunities to communicate in a credible manner or respond to others' challenges to her credibility.

Even when third parties, like advocates, attempt to challenge the discourse in what they consider the best interests of a refugee or refugees more generally, their actions are understood against the background of the dominant discourse on refugees. The centrality of refugees' credibility as a topic and the invisibility of their limited means as participants in challenging the discourse means that advocates' actions and words may be construed as the refugee's own words (as in the media reporting on Abyan), even where their input is unsolicited and therefore beyond the refugee's control.

Discourse produces what is 'sayable or unsayable, thinkable or unthinkable' (Bourdieu 1992: 172), and attributes more or less value to different forms of communication and identity types in particular settings. Effectively this means that credibility is a construct of this discourse rather than a phenomenon or attribute that exists in isolation.

The implications of the unequal resources uncovered in this analysis therefore extend beyond the individual case at hand, to the creation and preservation of dominant discourse on refugees and their credibility. Most obviously, their unequal communicative resources mean 
that different social actors have unequal means to produce, reproduce or challenge this discourse.

Further, the centrality of refugee credibility in the dominant discourse, or, in van Dijk's (2008) words, the fact that it is something that the public 'think about', helps preserve this very discourse: from the outset we are taught to focus on and question the credibility of those who may protest against the discourse and its detrimental effects.

The invisibility or erasure within the dominant discourse of the unequal communicative resources uncovered in the above analysis only further acts to entrench this inequality. It is not something the dominant discourse directs us to think about and is therefore more difficult to challenge.

This is problematic not only for equal participation in discourse production. It also has serious social and political implications. Control over discourse production means the ability to influence the status quo: discourse has the potential to "play a decisive role in the genesis, production and construction of certain social conditions' (van Leeuwen and Wodak 1999: 92). While focusing on refugees' credibility remains as politically expedient to Australian governments and opposition parties as it has been in recent decades, it will likely remain a key feature of the dominant discourse into the future. This discourse then justifies or even demands punitive policies that reflect a lack of trust in asylum seekers and refugees. For those seeking asylum in recent years, this has meant facing indefinite detention in Nauru or PNG, in conditions that have led to the deaths of at least twelve persons in the past five years, as a result of suicide, violence or unaddressed health needs (Doherty et al. 2018). Overall, these conditions have been found to constitute serious human rights abuses for thousands of men, women and children (UN Committee on Economic, Social and Cultural Rights 2017).

Dominant discourse that questions whether refugees are trustworthy or believable may also go some way to explaining the increasing centrality of credibility assessments in asylum applications. These mechanisms have been widely criticised (eg. Coffey 2003; Evans Cameron 2008; McKinnon 2009; Thomas 2011), with decision making in this setting described as involving a troubling 'presumptive skepticism' (Anker 1992; Byrne 2007). Further, the conceptualization of credibility in the public discourse, ignoring the socially situated nature of communication and erasing the inequalities discussed in this paper, may help explain similar constructions of credibility and communication uncovered in the decision-making context. There, much like in the above analysis, it has been found that refugees are disproportionately held responsible for communication and narrative creation, with the impacts of immediate 
interactions and broader legal, social and discursive structures largely erased (Smith-Khan 2017c, 2017a).

In 2003, Michael Clyne (2003: 5) responded to the advent of refugee-vilifying political discourse with a call for action, suggesting that 'we have a duty as linguists, when we see this happening, to alarm anyone who cares to listen' and encouraging a critical examination of how language can have an impact on social justice. Taking up the call for action, this case study responds to a pervasive discourse throughout refugee policy and decision making in the global north that presents refugees as isolated actors whose speech and actions should be interrogated to determine their credibility. It challenges this discourse by demonstrating the socially and discursively situated nature of refugees' communicative resources and thus the way these structures impact on their apparent credibility and on their ability to participate in and respond to discourse creation. 


\section{REFERENCES}

ABC Media Watch (2015). Exclusive Nauru access for The Australian, (updated 26 October 2015) $<$ http://www.abc.net.au/mediawatch/transcripts/s4339385.htm $>$, accessed 2 January 2018.

Allard, Tom (2015). Somalian refugee Abyan becomes a political pawn after abortion request on Nauru. Sydney Morning Herald, 24 October 2015.

Anderson, Stephanie (2015). Pregnant refugee Abyan to return to Australia from Nauru for medical treatment, Peter Dutton says. ABC News, 28 October 2015.

Angermeyer, Philipp Sebastian (2015). Speak English or What? Codeswitching and interpreter use in New York City courts, ed. Roger W. Shuy (Oxford Studies in Language and Law; New York: Oxford University Press).

--- (2016). Promoting litigant consent to arbitration in multingual Small Claims Court. In Susan Ehrlich, Diana Eades, and Janet Ainsworth (eds.), Discursive Constructions of Consent in the Legal Process, 163. New York: Oxford University Press.

Anker, Deborah (1992). Determining Asylum Claims in the United States: A case study of the implementation of legal norms in an unstructured adjudicatory environment. $N Y U$ Review of Law and Social Change 19: 433-528.

Appelman, Alyssa and Bolls, Paul (2011). Article Recall, Credibility Lower with Grammar Errors. Newspaper Research Journal 32 (2): 50-62.

Baillot, Helen, Cowan, Sharon, and Munro, Vanessa E (2014). Reason to disbelieve: evaluating the rape claims of women seeking asylum in the UK. International Journal of Law in Context 10 (1): 105.

Bleiker, Roland, et al. (2013). The visual dehumanisation of refugees. Australia Journal of Political Science 48 (4): 398-416.

Blommaert, Jan (2004). Writing as a problem: African grassroots writing, economies of literacy, and globalization. Language in Society 33 (5): 643-71.

--- (2010). The Sociolinguistcs of Globalization, ed. Salikoko S. Mufwene (Cambridge Approaches to Language Contact; Cambridge: Cambridge University Press).

Bourdieu, Pierre (1992). Language and Symbolic Power (Cambridge: Polity Press).

Bourke, Latika (2015). Peter Dutton says advocates for Somali refugee 'Abyan' have let her down Sydney Morning Herald, 19 October 2015.

Byrne, Rosemary (2007). Assessing Testimonial Evidence in Asylum Proceedings: Guiding Standards from the International Criminal Tribunals. International Journal of Refugee Law 19 (4): 609-38.

Campbell, John (2013). Language analysis in the United Kingdom's refugee status determination system: seeing through policy claims about "expert knowledge". Ethnic and Racial Studies 36 (4): 670-90.

Capstick, Tony (2016). Multilingual Literacies, Identities and Ideologies: Exploring Chain Migration from Pakistan to the UK (London: Palgrave Macmillan).

Central Intelligence Agency (2018). The World Factbook: Nauru, $<$ https://www.cia.gov/library/publications/the-world-factbook/geos/nr.html $>$, accessed.

Clyne, Michael (2003). When the discourse of hatred becomes respectable does the linguist have a responsibility? Australia Review of Applied Linguistics 26 (1): 1-5.

Coffey, Guy (2003). The Credibility of Credibility Evidence at the Refugee Review Tribunal. International Journal of Refugee Law 15: 377-417.

Corcoran, Chris (2004). A critical examination of the use of language analysis interviews in asylum proceedings: a case study of a West African seeking asylum in The Netherlands. International Journal of Speech, Language and the Law 11 (2): 200-21. 
Davidson, Helen (2017). Peter Dutton introduces bill to ban phones from immigration detainees. The Guardian, 13 September 2017.

Doherty, Ben (2015). Nauru police close case of alleged rape of Somali reufgee citing lack of evidence. The Guardian, 12 October 2015.

Doherty, Ben and Medhora, Shalailah (2015). Somali refugee flown out of Australia denies saying she declined termination. The Guardian, 19 October 2015.

Doherty, Ben, Evershed, Nick, and Ball, Andy (2018). Deaths in offshore detention: the faces of the people who have died in Australia's care. The Guardian, 20 June 2018.

Eades, Diana (2003). Participation of second language and second dialect speakers in the legal system. Annual Review of Applied Linguistics 23: 113-33.

--- (2005). Applied Linguistics and Language Analysis in Asylum Seeker Cases. Applied Linguistics 26 (4): 503-26.

--- (2008). Telling and retelling your story in court: Questions, assumptions and intercultural implications. Current Issues in Criminal Justice November 2008: 209-30.

--- (2009). Testing the Claims of Asylum Seekers: The Role of Language Analysis. Language Assessment Quarterly 6 (1): 30-40.

--- (2012). The social consequences of language ideologies in courtroom cross-examination. Language in Society 41 (4): 471-97.

Evans Cameron, Hilary (2008). Risk Theory and "Subjective Fear": The Role of Risk Perception, Assessment, and Management in Refugee Status Determinations. International Journal of Refugee Law 20 (4): 567-85.

Every, Danielle and Augoustinos, Martha (2008). "Taking advantage" or fleeing persecution? Opposing accounts of asylum seeking. Journal of Sociolinguistics 12 (5): 648.

Gartrell, Adam (2017). Peter Dutton abandons detention centre secrecy rules amid High Court challenge. Sydney Morning Herald, 13 August 2017.

Grattan, Michelle (2015). A counsellor should be sent to Nauru to help 'Abyan'. The Conversation, 19 October 2015.

Hamlin, Rebecca (2014). Let me be a refugee: Administrative justice and the politics of asylum in the United States, Canada, and Australia (Oxford Scholarship Online).

Healicon, Alison (2016). The Politics of Sexual Violence: Rape, Identity and Feminism (Basingstoke: Palgrave Macmillan).

Hymes, Dell (1974). Foundations of Sociolinguistics: An Ethnographic Approach (Philadelphia: University of Pennsylvania Press).

Jacquemet, Marco (2011). Crosstalk 2.0: asylum and communicative breakdowns. Text \& Talk 31 (4): 475-97.

Jeong, Allan, Li, Haiying, and Pan, Andy Jiaren (2017). A sequential analysis of responses in online debates to postings of students exhibiting high versus low grammar and spelling errors. Education Technology Research and Development 65 (5): 1175-94.

Kelly, Joe (2015). Nauru offers home to hundreds as asylum rape battle rages. The Australian, 19 October 2015.

Kenny, Chris (2015). Refugee declines to report rape to police. The Australian, 21 October 2015.

KhosraviNik, Majid (2009). The representation of refugees, asylum seekers and immigrants in British newspapers during the Balkan conflict (1999) and the British general election (2005). Discourse \& Society 20 (4): 477-98.

Lawlor, Andrea and Tolley, Erin (2017). Deciding who's legitimate: News media framing of immigrants and refugees. International Journal of Communication 11: 967-91.

Lindemann, Stephanie and Moran, Katherine (2017). The role of the descriptor "broken English" in ideologies about nonnative speech. Language in Society 46: 649-69. 
MacCallum, Mungo (2002). Girt by sea: Australia, the refugees and the politics of fear (Melbourne: Black Inc).

Macken-Horarik, Mary (2003a). Working the borders in racist discourse: The challenge of the "Children Overboard Affair" in news media texts. Social Semiotics 13 (3): 283303.

--- (2003b). A telling symbiosis on the discourse of hatred: Multimodal news texts about the "Children Overboard" affair. Australian Review of Applied Linguistics 26 (2): 1-16.

Martin-Lacroux, Christelle (2017). "Without the spelling errors I would have shortlisted her...": The impact of spelling errors on recruiters' choice during the personnel selection process. International Journal of Selection and Assessment 25 (3): 276-83.

Maryns, Katrijn (2004). Identifying the asylum speaker: reflections on the pitfalls of language analysis in the determination of national origin. international Journal of Speech, Language and the Law 11 (2): 240-60.

McKinnon, Sara L. (2009). Citizenship and the Performance of Credibility: Audiencing Gender-based Asylum Seekers in U.S. Immigration Courts. Text and Performance Quarterly 29 (3): 205-21.

McKnight, David (2012). Henry Mayer Lecture 2012: The Market Populism of Rupert Murdoch. Media International Australia (144): 5-12.

Newhouse, George (2015). This young girl was raped and left stranded - bring her to Australia for urgent treatment, $<$ https://www.change.org/p/malcolm-turnbull-thisyoung-girl-was-raped-and-left-stranded-bring-her-to-australia-for-urgent-treatment $>$, accessed.

Opeskin, Brian and Ghezelbash, Daniel (2016). Australian refugee policy and its impacts on Pacific Island countries. The Journal of Pacific Studies 36 (1): 73-90.

Pickering, Sharon (2001). Common sense and original deviancy: News discourses and asylum seekers in Australia. Journal of Refugee Studies 14 (2): 169.

Piller, Ingrid (2016). Linguistic Diversity and Social Justice (Oxford: Oxford University Press).

--- (2017). Intercultural Communication: A Critical Introduction (2 edn.; Edinburgh: Edinburgh University Press).

Sky News Chris Kenny, < $\underline{\text { http://www.skynews.com.au/connect/sky-news-team/chris- }}$ kenny.html>, accessed 16 March 2018.

Smith-Khan, Laura (2017a). Telling stories: Credibility and the representation of social actors in Australian asylum appeals. Discourse \& Society 28 (5): 512-34.

--- (2017b). Negotiating Narratives, Accessing Asylum: Evaluating language policy as multilevel practice, beliefs and management Multilingua 36 (1): 31-57.

--- (2017c). Different in the same way?: Language, diversity and refugee credibility. International Journal of Refugee Law 29 (3): 389-416.

--- (Under review). Debating credibility: Refugees and rape in the media.

Stirling, Angus (2015), 'Asylum seekers and refugees in Australian print media: A corpusassisted critical discourse analysis', Linguistic Society of New Zealand 2015 Conference (University of Otago).

Sweeney, James A. (2009). Credibility, proof and refugee law. International Journal of Refugee Law 21 (4): 700-26.

Symons-Brown, Bonny (2016). Pregnant Somali asylum seeker Abyan had not ruled out abortion, FOI documents reveal. ABC News, 2 January 2016.

Teo, Peter (2000). Racism in the news: a Critical Discourse Analysis of news reporting in two Australian newspapers. Discourse \& Society 11 (1): 7-49. 
The Government of the Republic of Nauru (2017). Visa Requirements, $<\underline{\text { http://www.naurugov.nr/about-nauru/visiting-nauru/visa-requirements.aspx }}>$, accessed.

Thomas, Robert (2011). Administrative Justice and Asylum Appeals: A study of tribunal adjudication (Oxford and Portland, Oregon: Hart Publishing).

Tranter, Kellie (2016). Immigration officials knew refugee Abyan still wanted abortion, emails show. The Guardian, 2 January 2016.

UN Committee on Economic Social and Cultural Rights (2017), 'Concluding observations on the fifth periodic report of Australia', (E/C.12/AUS/CO/5).

van Dijk, Teun A (2006). Discourse, context and cognition. Discourse Studies 8 (1): 159-77.

--- (2008). Discourse and Power (Basingstoke: Palgrave Macmillan).

van Leeuwen, Theo (1996). The representation of social actors. In C R Caldas-Coulthard and

M Coulthard (eds.), Texts and Practices: Readings in critical discourse analysis, 32-

70. London: Routledge.

--- (2007). Legitimation in discourse and communication. Discourse \& Communication 1 (1): 91-112.

van Leeuwen, Theo and Wodak, Ruth (1999). Legitimizing immigration control: a discoursehistorical analysis. Discourse Studies 1 (1): 83-118.

Whyte, Sarah (2017). Government pays compensation to Save the Children workers removed from Nauru. $A B C$ News, 31 January 2017.

Wolfe, Joanna, Shanmugaraj, Nisha, and Sipe, Jaclyn (2016). Grammatical versus pragmatic error: Employer perceptions of nonnative and native English speakers. Business and Professional Communication Quarterly 79 (4): 397-415. 